\title{
How are podocytes affected in nail-patella syndrome?
}

\author{
Ralph Witzgall
}

Received: 30 September 2007 / Revised: 30 October 2007 / Accepted: 16 November 2007 / Published online: 6 February 2008

(C) IPNA 2007

\begin{abstract}
Nail-patella syndrome is an autosomal-dominant hereditary disease named for dysplastic fingernails and toenails and hypoplastic or absent kneecaps evident in patients with the syndrome. Prognosis is determined by the nephropathy that develops in many such patients. Besides podocyte foot-process effacement, pathognomonic changes in the kidney comprise electron-lucent areas and fibrillar inclusions in the glomerular basement membrane. These characteristic symptoms are caused by mutations in the gene encoding the transcription factor $L M X 1 B$, a member of the LIM-homeodomain gene family. Comparable with the human syndrome, homozygous $L m x l b$ knockout mice lack patellae and suffer from severe podocyte damage. In contrast, however, podocin and the $\alpha 3$ and $\alpha 4$ chains of collagen IV are absent in the glomeruli of Lmxlb knockout mice. Further studies with podocyte-specific $L m x l b$ knockout mice have confirmed the importance of LMX1B in podocytes, as these mice apparently develop foot processes initially but lose them later on. We therefore conclude that LMX1B is essential for the development of metanephric precursor cells into podocytes and possibly also for maintaining the differentiation status of podocytes. LMX1B can serve as a model system to elucidate a genetic program in podocytes.
\end{abstract}

Keywords LMX1B - Mouse model Podocyte foot process · Slit diaphragm $\cdot$ Promotor analysis $\cdot$ Target genes

\footnotetext{
R. Witzgall $(\triangle)$

University of Regensburg,

Institute for Molecular and Cellular Anatomy,

Universitätsstrasse 31 ,

93053 Regensburg, Germany

e-mail: ralph.witzgall@vkl.uni-regensburg.de
}

For many years, the mesangial cell took the forefront of glomerular research (see, for example, [1, 2]), but its pedestal was first slowly shaken by the painstaking morphological investigations of Wilhelm Kriz (confer [3, 4] for an early and late review, respectively) and finally abruptly toppled by irrefutable genetic evidence pointing towards the podocyte as a crucial cell in the glomerulus [5]. Meanwhile, the podocyte is firmly rooted in pathogenetic models of glomerular diseases and it is hard to imagine that it will leave again. Although mutations in WT1, a gene encoding a transcription factor of the $\mathrm{Cys}_{2} \mathrm{His}_{2}$-zinc finger family, had been found responsible for the podocytopathies Denys-Drash syndrome [6], WAGR syndrome [7] and Frasier syndrome [8], the article by Karl Tryggvason's group on the identification of mutations in NPHS1 added another dimension [5]. NPHS1 is mutated in patients suffering from congenital nephrotic syndrome of the Finnish type. It codes for nephrin, a component of the slit diaphragm, and therefore is an essential part of the glomerular filtration barrier [9-11]. Since then several other genes have been cloned that when mutated lead to glomerular disease and which in the kidney are (almost) specifically expressed in podocytes. They are $L M X 1 B$ [12-14], NPHS2, the gene encoding podocin [15]; ACTN4, the gene encoding $\alpha$-actinin-4 [16]; CD2AP [17, 18] and TRPC6 $[19,20]$. In the following years, an increasing amount of evidence has accumulated on the specific role of these proteins in the podocyte. Nephrin and podocin participate in the formation of the slit diaphragm complex, $\alpha$-actinin- 4 crosslinks actin filaments in podocytes, and TRPC6 belongs to a special class of cation channels. Very little, however, is known about how the podocyte-specific expression of these genes is achieved. The sparse evidence that has been published concerns WT1, which binds to sequences in the promoter regions of the Podxl gene (encoding podocalyxin) [21] and of the NPHS1/NphsIgene [22, 23]. Although WT1 
activates the respective reporter constructs, the induction of the endogenous NPHS1/Nphs1 gene by WT1 was described by one group [23] but not another [22].

Nail-patella syndrome has been known for many decades as a hereditary disease and was one of the first genetic disorders for which linkage was established. In addition to the obvious limb abnormalities, nephrologic symptoms develop in $\sim 40 \%$ of these patients over the course of several decades. On an ultrastructural level, the moth-eaten appearance of the glomerular basement membrane together with fibrillar deposits is considered typical of nail-patella syndrome. In addition, podocytes lose their foot processes (for references, see [24]). In 1998, not only were the first mutations in the $L M X 1 B$ gene published for patients suffering from nail-patella syndrome [12-14], but a report also appeared on the first characterisation of the $L m x 1 b$ knock-out mouse [25]. A more careful analysis of the kidney phenotype in the Lmxlb knock-out mouse revealed pronounced retardation in the development of podocytes that did not elaborate foot processes and slit diaphragms. Consistent with this finding was the splitting of the glomerular basement membrane and the reduced number of endothelial fenestrations, because podocytes synthesise proteins of the glomerular basement membrane and control differentiation of glomerular endothelial cells [26, 27]. Attractive explanations for these morphological defects have come from the observations that the $\alpha 3$ and $\alpha 4$ chains of collagen IV are no longer detected in the glomerular basement membrane ([28] and personal observations), that the Nphs2 gene is no longer expressed in podocytes of homozygous $L m x 1 b$ knock-out mice, and that podocytes in homozygous $L m x 1 b$ knock-out mice produce less vascular endothelial growth factor (VEGF) [26, 27]. Further molecular analysis demonstrated that LMX1B bound to AT-rich sequences in the first intron of the COL4A4 gene [28] and in the promoter region of the NPHS2 gene [26, 27].

Although the model that LMX1B activates the expression of COL4A4 and NPHS2, and that inactivating mutations in the $L M X 1 B$ gene secondarily lead to the loss of collagen IV and podocin and therefore to the characteristic alterations in nail-patella syndrome patients certainly is an attractive one, several caveats have to be mentioned as well. Firstly, we could not demonstrate activation of a reporter construct with $4.4 \mathrm{kbp}$ of the NPHS2 promoter by LMX1B [27], although another group showed an approximate twofold activation of the reporter gene controlled by four concatemerised LMX1B binding sites from the NPHS2 promoter [26]. Secondly, when we stably transfected a human cervical carcinoma cell line HeLa cells (which admittedly bears only a very remote similarity to podocytes) with an LMX1B cDNA, we found no upregulation of the endogenous NPHS2 gene [27]. Thirdly, podocin and the $\alpha 3$ and $\alpha 4$ chains of collagen IV were still present in glomeruli from patients with nail-patella syndrome [29]. And fourthly, the constitutive podocyte-specific inacti-
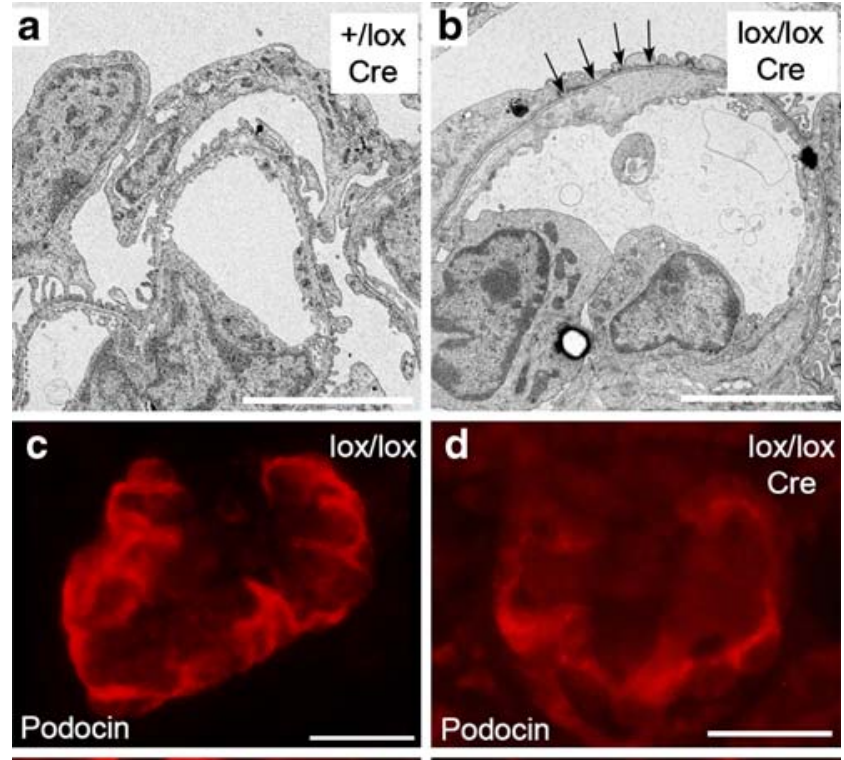

Iox/lox

Cre
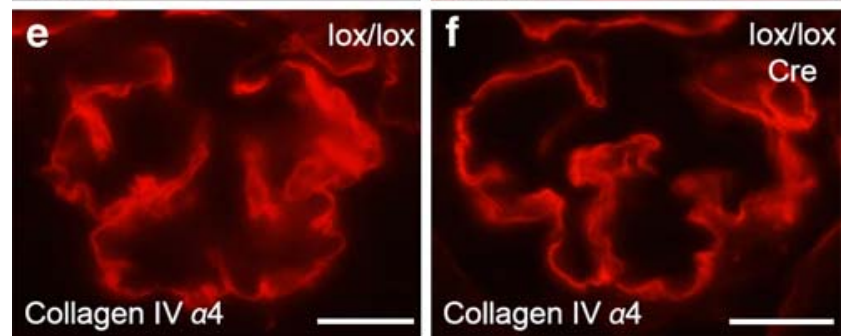

Fig. 1 a-f Ultrastructural and immunohistochemical characterisation of mice with podocyte-specific inactivation of $L m x I b$. In 11-day-old mice, the podocyte-specific inactivation of $L m x l b$ leads to the loss of foot processes and to a thickened glomerular basement membrane (arrows in b). However, despite the inactivation of $L m x 1 b$, podocin and the $\alpha 4$ chain of collagen IV are still produced $(\mathbf{d}, \mathbf{f}) .+/$ lox control mice with one wild-type and one floxed Lmxlb allele; lox/lox mice with two floxed $L m x I b$ alleles; Cre presence of the Cre transgene under control of the human NPHS2 promoter. Bars: $5 \mu \mathrm{m}(\mathbf{a}, \mathbf{b})$, $20 \mu \mathrm{m}(\mathbf{c}-\mathbf{f})$. With permission from [30]

vation of Lmxlb in the mouse does not lead to the loss of podocin or collagen IV [30]. What do these apparently discrepant results mean? If LMX1B already acts at a very early stage of podocyte development, specifically before the NPHS2, COL4A3 and COL4A4 genes are turned on (by other transcription factors?), the podocyte will just not have reached an advanced enough stage of development to produce podocin and collagen IV. In other words, LMX1B may rather exert a permissive influence and, for example, initiate the spreading of the foot processes upon which podocin would be produced and slit diaphragms be elaborated.

The constitutive podocyte-specific inactivation of $L m x 1 b$ represents a more comparable model for human nephropathy, but the mice only survive for $\sim 2$ weeks after birth [30], again limiting their usefulness. In those animals, podocin and collagen IV $\alpha 3 / \alpha 4$ are still present, and it appears as if foot processes and slit diaphragms are first elaborated and then lost secondarily (Fig. 1). Does LMX1B therefore play a role not only for the initial development of 
podocytes but also in the maintenance of their differentiation status? Clearly, more elaborate mouse models with an inducible inactivation of $L m x l b$ in adult animals are needed to answer this question. Such mice will also have the additional advantage of permitting the isolation of sufficient amounts of glomeruli, which can be used for DNA microarrays and identification of LMX1B target genes. Mouse genetics has already provided us with the verification of LDB1 as an interaction partner of LMX1B [30], and it may in the end help us to identify a genetic hierarchy acting in podocytes by telling us what factors control the expression of $L M X 1 B$ in podocytes, what other proteins LMX1B interacts with and what genes are regulated by LMX1B in this peculiar cell type.

Acknowledgements Financial support from the German Research Council through SFB 699 is gratefully acknowledged.

\section{References}

1. Fogo AB (1999) Mesangial matrix modulation and glomerulosclerosis. Exp Nephrol 7:147-159

2. Schöcklmann HO, Lang S, Sterzel RB (1999) Regulation of mesangial cell proliferation. Kidney Int 56:1199-1207

3. Kriz W, Gretz N, Lemley KV (1998) Progression of glomerular disease: Is the podocyte the culprit? Kidney Int 54:687-697

4. Kriz W, LeHir M (2005) Pathways to nephron loss starting from glomerular diseases-insights from animal models. Kidney Int 67:404-419

5. Kestilä M, Lenkkeri U, Männikkö M, Lamerdin J, McCready $P$, Putaala H, Ruotsalainen V, Morita T, Nissinen M, Herva R, Kashtan CE, Peltonen L, Holmberg C, Olsen A, Tryggvason K (1998) Positionally cloned gene for a novel glomerular proteinnephrin-is mutated in congenital nephrotic syndrome. Mol Cell 1:575-582

6. Pelletier J, Bruening W, Kashtan CE, Mauer SM, Manivel JC, Striegel JE, Houghton DC, Junien C, Habib R, Fouser L, Fine RN, Silverman BL, Haber DA, Housman D (1991) Germline mutations in the Wilms' tumor suppressor gene are associated with abnormal urogenital development in Denys-Drash syndrome. Cell 67:437-447

7. Ton CTT, Hirvonen H, Miwa H, Weil MM, Monaghan P, Jordan T, van Heyningen V, Hastie ND, Meijers-Heijboer H, Drechsler M, Royer-Pokora B, Collins F, Swaroop A, Strong LC, Saunders GF (1991) Positional cloning and characterization of a paired boxand homeobox-containing gene from the aniridia region. Cell 67:1059-1074

8. Barbaux S, Niaudet P, Gubler M-C, Grünfeld J-P, Jaubert F, Kuttenn F, Fékété CN, Souleyreau-Therville N, Thibaud E, Fellous M, McElreavey K (1997) Donor splice-site mutations in WT1 are responsible for Frasier syndrome. Nat Genet 17:467-470

9. Holthöfer H, Ahola H, Solin M-L, Wang S, Palmen T, Luimula P, Miettinen A, Kerjaschki D (1999) Nephrin localizes at the podocyte filtration slit area and is characteristically spliced in the human kidney. Am J Pathol 155:1681-1687

10. Holzman LB, St. John PL, Kovari IA, Verma R, Holthofer H, Abrahamson DR (1999) Nephrin localizes to the slit pore of the glomerular epithelial cell. Kidney Int 56:1481-1491

11. Ruotsalainen V, Ljungberg P, Wartiovaara J, Lenkkeri U, Kestilä M, Jalanko H, Holmberg C, Tryggvason K (1999) Nephrin is specifically located at the slit diaphragm of glomerular podocytes. Proc Natl Acad Sci USA 96:7962-7967

12. Dreyer SD, Zhou G, Baldini A, Winterpacht A, Zabel B, Cole W, Johnson RL, Lee B (1998) Mutations in LMX1B cause abnormal skeletal patterning and renal dysplasia in nail patella syndrome. Nat Genet 19:47-50

13. McIntosh I, Dreyer SD, Clough MV, Dunston JA, Eyaid W, Roig CM, Montgomery T, Ala-Mello S, Kaitila I, Winterpacht A, Zabel B, Frydman M, Cole WG, Francomano CA, Lee B (1998) Mutation analysis of $L M X 1 B$ gene in nail-patella syndrome patients. Am J Hum Genet 63:1651-1658

14. Vollrath D, Jaramillo-Babb VL, Clough MV, McIntosh I, Scott KM, Lichter PR, Richards JE (1998) Loss-of-function mutations in the LIM-homeodomain gene, $L M X 1 B$, in nail-patella syndrome. Hum Mol Genet 7:1091-1098

15. Boute N, Gribouval O, Roselli S, Benessy F, Lee H, Fuchshuber A, Dahan K, Gubler M-C, Niaudet P, Antignac C (2000) NPHS2, encoding the glomerular protein podocin, is mutated in autosomal recessive steroid-resistant nephrotic syndrome. Nat Genet 24: 349-354

16. Kaplan JM, Kim SH, North KN, Rennke H, Correia LA, Tong $\mathrm{H}-\mathrm{Q}$, Mathis BJ, Rodríguez-Pérez J-C, Allen PG, Beggs AH, Pollak MR (2000) Mutations in ACTN4, encoding $\alpha$-actinin-4, cause familial focal segmental glomerulosclerosis. Nat Genet $24: 251-256$

17. Kim JM, Wu H, Green G, Winkler CA, Kopp JB, Miner JH, Unanue ER, Shaw AS (2003) CD2-associated protein haploinsufficiency is linked to glomerular disease susceptibility. Science 300:1298-1300

18. Löwik MM, Groenen PJTA, Pronk I, Lilien MR, Goldschmeding R, Dijkman HB, Levtchenko EN, Monnens LA, van den Heuvel LP (2007) Focal segmental glomerulosclerosis in a patient homozygous for a CD2AP mutation. Kidney Int 72:1198-1203

19. Reiser J, Polu KR, Möller CC, Kenlan P, Altintas MM, Wei C, Faul C, Herbert S, Villegas I, Avila-Casado C, McGee M, Sugimoto H, Brown D, Kalluri R, Mundel P, Smith PL, Clapham DE, Pollak MR (2005) TRPC6 is a glomerular slit diaphragmassociated channel required for normal renal function. Nat Genet 37:739-744

20. Winn MP, Conlon PJ, Lynn KL, Farrington MK, Creazzo T, Hawkins AF, Daskalakis N, Kwan SY, Ebersviller S, Burchette JL, Pericak-Vance MA, Howell DN, Vance JM, Rosenberg PB (2005) A mutation in the TRPC6 cation channel causes familial focal segmental glomerulosclerosis. Science 308:1801-1804

21. Palmer RE, Kotsianti A, Cadman B, Boyd T, Gerald W, Haber DA (2001) WT1 regulates the expression of the major glomerular podocyte membrane protein Podocalyxin. Curr Biol 11:1805-1809

22. Guo G, Morrison DJ, Licht JD, Quaggin SE (2004) WT1 activates a glomerular-specific enhancer identified from the human nephrin gene. J Am Soc Nephrol 15:2851-2856

23. Wagner N, Wagner K-D, Xing Y, Scholz H, Schedl A (2004) The major podocyte protein nephrin is transcriptionally activated by the Wilms' tumor suppressor WT1. J Am Soc Nephrol 15:3044-3051

24. Rascle A, Suleiman H, Neumann T, Witzgall R (2007) Role of transcription factors in podocytes. Nephron Exp Nephrol 106: e60-e66

25. Chen H, Lun Y, Ovchinnikov D, Kokubo H, Oberg KC, Pepicelli CV, Gan L, Lee B, Johnson RL (1998) Limb and kidney defects in $L m x 1 b$ mutant mice suggest an involvement of $L M X 1 B$ in human nail patella syndrome. Nat Genet 19:51-55

26. Miner JH, Morello R, Andrews KL, Li C, Antignac C, Shaw AS, Lee B (2002) Transcriptional induction of slit diaphragm genes by $\mathrm{Lmx} 1 \mathrm{~b}$ is required in podocyte differentiation. J Clin Invest 109:1065-1072

27. Rohr C, Prestel J, Heidet L, Hosser H, Kriz W, Johnson RL, Antignac C, Witzgall R (2002) The LIM-homeodomain transcription 
factor Lmx1b plays a crucial role in podocytes. J Clin Invest 109:1073-1082

28. Morello R, Zhou G, Dreyer SD, Harvey SJ, Ninomiya Y, Thorner PS, Miner JH, Cole W, Winterpacht A, Zabel B, Oberg KC, Lee B (2001) Regulation of glomerular basement membrane collagen expression by $L M X 1 B$ contributes to renal disease in nail patella syndrome. Nat Genet 27:205-208

29. Heidet L, Bongers EMHF, Sich M, Zhang S-Y, Loirat C, Meyrier A, Broyer M, Landthaler G, Faller B, Sado Y, Knoers
NVAM, Gubler M-C (2003) In vivo expression of putative $L M X 1 B$ targets in nail-patella syndrome kidneys. Am J Pathol 163:145-155

30. Suleiman H, Heudobler D, Raschta A-S, Zhao Y, Zhao Q, Hertting I, Vitzthum H, Moeller MJ, Holzman LB, Rachel R, Johnson R, Westphal H, Rascle A, Witzgall R (2007) The podocyte-specific inactivation of $L m x I b, L d b 1$ and $E 2 a$ yields new insight into a transcriptional network in podocytes. Dev Biol 304:701-712 